\title{
MECHANISMS OF THE ELECTRON-INDUCED ALANINE MOLECULE FRAGMENTATION
}

\author{
J. Tamulienè ${ }^{\text {a }}$, L.G. Romanova ${ }^{\text {b }}$, V.S. Vukstich ${ }^{\text {b }}$, and A.V. Snegursky ${ }^{b}$ \\ a Institute of Theoretical Physics and Astronomy, Vilnius University, A. Goštauto 12A, LT-01108 Vilnius, Lithuania \\ ${ }^{\mathrm{b}}$ Institute of Electron Physics, Ukr. Nat. Acad. Sci., Universitetska 21, 88017 Uzhgorod, Ukraine \\ E-mail: jelena.tamuliene@tfai.vu.lt
}

Received 11 May 2013; revised 13 August 2013; accepted 4 December 2013

\begin{abstract}
The fragmentation of the alanine $\left(\mathrm{C}_{3} \mathrm{H}_{7} \mathrm{NO}_{2}\right)$ molecule due to the low-energy electron impact was studied both experimentally and theoretically using the mass spectroscopic technique combined with the density functional theoretical approach. The main emphasis was given to the mechanisms of initial molecule fragment production. Special attention was paid to the energy characteristics of the ionic fragment yield. The geometrical parameters of initial molecule rearrangement were also analysed.
\end{abstract}

Keywords: fragmentation, amino acid, low-energy electron impact, mass spectra, appearance energy

PACS: 82.30.Lp

\section{Introduction}

Alanine is a nonessential amino acid, i. e. it can be manufactured by the human body and does not need to be obtained directly through the diet. L-alanine is the second after leucine in the rate of occurrence, accounting for $7.8 \%$ of the primary structure of proteins [1, 2]. It is necessary to mention that this molecule is often considered to be a model system for studying the properties of more complex systems, particularly in case of ionizing radiation influence [3]. Alanine due to its radiation doimetric properties is considered a secondary standard for the highdose and transfer dosimetry [4, 5. Additionally, the studies of this molecule fragmentation have a great astrophysical importance due to the dominant role of ionic species with a loss of neutral $\mathrm{COOH}$ as well as a protonated hydrogen cyanide $\mathrm{HCNH}^{+}$ ion [6]. Generally, there exist two structural alanine conformers, i. e. the $\alpha$-alanine, in which the amine group is at the $\alpha$-C atom, and the $\beta$-alanine, in which the amine group is at the $\beta$-C atom. The $\alpha$-alanine molecule possesses a considerable optical activity due to the presence of a chiral carbon atom. Optical alanine conformers (L, D) differ by the substituent locations in one $\mathrm{C}$ atom. In addition, this molecule like many other biomolecules may exist as a number of conformers, and even thermal energies may easily transform this molecule from one conformer to the other one [7, 8]. Note that in our studies we dealt with the $\alpha$-alanine molecule.

The interaction of ionizing radiation with the matter produces secondary reactive species along the track of the high-energy projectile. These secondary species may undergo subsequent reactions with the medium. Kinetic energy of some of secondary electrons is sufficient to induce electron impact ionization, dissociative electron impact ionization and isomerization as well. These reactions are responsible for the formation of positive/negative ions, neutral 
fragments, and radicals and may play an important role in the formation of radicals from alanine. In some cases, they could lead to dissociative electron attachment, i. e. fragmentation accompanied by the negative fragment ion yield (see, e. g. [9]). It is no doubt that the appearance energies of ion production during electron impact ionization from different conformers will be different. Hence, in the present paper, we report on the results of both experimental and theoretical studies on the electron impact fragmentation of the DL $\alpha$-alanine molecule, while several conformers of the molecule were investigated theoretically only. The results obtained are compared with those of other theoretical and experimental studies of L-alanine [9].

A theoretical method was used to predict all possible fragmentation channels and processes that could occur under electron impact, while the comparison of theoretical results with experimentally measured ones allowed us to check theoretical predictions made, choose the dominant fragmentation pathways, and describe fragmentation processes more correctly. Hence, the goal of our studies was to elucidate the major channels of the alanine molecule fragmentation caused by low-energy electron impact.

\section{Experiment}

The experimental technique used in the present study was described in detail in our previous papers (see, e. g. [10, 11]). A crossed-beam method accompanied by the mass separation of the collision products by means of a magnetic mass spectrometer was applied. It is emphasized that our apparatus is capable of studying ionic fragments with respect to their mass-to-charge ratio $\mathrm{m} / z$ within the $1-720$ Th mass range with high sensitivity $\left(\sim 10^{-16} \mathrm{~A}\right)$ and relative mass resolution $(m / \Delta m=1100)$. Below we will use the $[\mathrm{Th}]$ units to denote the mass of the fragments produced, keeping in mind that strictly it means the mass-to-charge ratio $\mathrm{m} / \mathrm{z}$. The alanine molecule beam was produced by a heated effusion source providing molecular concentrations of about $10^{10} \mathrm{~cm}^{-3}$. The electron energy scale calibration was carried out against known ionization thresholds for the Ar atom and $\mathrm{N}_{2}$ molecule ensuring the calibration accuracy not worse than $\pm 0.1 \mathrm{eV}$ to be reached [10]. The alanine molecule mass spectrum was measured at the $70 \mathrm{eV}$ electron energy, while the appearance energies for the positively charged fragment ions were determined within the $5-30 \mathrm{eV}$ energy range by using the technique described in detail in [10-12].

\section{Theoretical part}

The structure of the molecule and its fragments has been studied by Becke's three-parameter hybrid functional applying the non-local correlation provided by Lee, Yang, and Parr (B3LYP) [13] - a representative standard DFT method. The most significant advantage of the DFT method is a significant increase in computational accuracy without additional increase in computing time [14]. The present DFT method is derived for obtaining total energies as the function of the nuclei position and is often the method of choice for reaction calculations because the electron correlation energy is accounted, while ignoring the electron correlation is one of the most significant deficiencies of the Hartree-Fock method. However, the correlation energy as well as the total energy of the investigated system is highly dependent on the basis set used. Thus, our investigation was performed with the cc-pVTZ basis - a contracted basis set, which takes into account correlation effects with a (12s $6 \mathrm{p})$ primitive basis set contracted under the Raffenetti scheme and optimized at the HF level [15]. It should be mentioned that the basis set is smaller than that of Gaussian type such as 6-31G, 6-311G, etc., thus, high accuracy of calculations is achieved with additional increase in computing time and resources [16, 17]. The structure parameters of the molecule and its fragments under study have been optimized with no symmetry constraint. The results of analysing the bond order and the bond length of the alanine molecule conformers were used to find the weaker and the most probable bonds to be destructed. In order to model the fragmentation processes, the possible fragment anions, cations, and fragments with a zero charge both with and without geometry optimization have been analysed to predict the influence of dissociation energy on the fragmentation processes. The appearance energies were calculated as a difference between the total energy of the alanine molecule and the sum of the total energies of the fragments predicted, while in order to evaluate the above influence we have studied the following two cases: 
(i) the single point energy calculation for the fragments was performed taking into account the geometry of a certain part of the alanine molecule (in these cases the energy of fragment formation is not the lowest one);

(ii) the structure parameters of alanine fragments were optimized, i. e. the fragments were allowed to reach their equilibrium geometry, and the obtained energy (the lowest energy of the fragments) was used to calculate the dissociation energy.

Using this methodology, we took into account the processes when the molecular ions formed with energies just in excess of the ionization potential may have no sufficient energy to be decomposed according to the lowest energy pathway and, thus, will be detected in the experiment directly [18]. The GAMESS and the Gaussian program packages were applied here [19, 20].

\section{Results and discussion}

In the present study, the DL $\alpha$-alanine in a form of a crystalline powder of $99 \%$ minimal purity was used without any further purification. The views of the conformers of the alanine molecule are shown in Fig. 1. According to our calculations, the total energies of three most stable conformers of the alanine molecule differ insignificantly. The results of our calculations agree well with those of other authors [21].
It is emphasized that the goal of our paper was to find the most energetically favourable fragmentation reactions in the alanine molecule under the low-energy electron impact, but not to find the structure of the most stable conformer. Hence, we have investigated fragmentation of two conformers called elsewhere as the most stable ones. For the hydrogenbonded systems, the structural rearrangement following ionization of such a molecule is quite typical [7]; however, each conformer of alanine can have somewhat different fragmentation pathways associated with the intramolecular hydrogen bonding.

According to our theoretical investigations, the most stable conformer is the alanine II (in our notation), the energy of which is by $0.054 \mathrm{eV}$ lower than that of the alanine I and the smallest energy barrier for the transition of the alanine III to the alanine I in the ground state due to rotation of the $-\mathrm{COOH}$ group is only $0.086 \mathrm{eV}$. The energy difference is approximately $0.02 \mathrm{eV}$ when the alanine III transits to the alanine I, i. e. it is equal to the thermal energy $k T$ at room temperature, while the above barrier is much smaller than the energy of the incident electron. Additionally, theoretical results exhibit that the equilibrium structure of the ionized alanine III molecule is like that of the alanine I molecule, i. e. the main structural difference between the alanine III and the alanine I disappears when these molecules are ionized. Thus, we intend to investigate theoretically the fragmentation of alanine I and alanine II conformers.
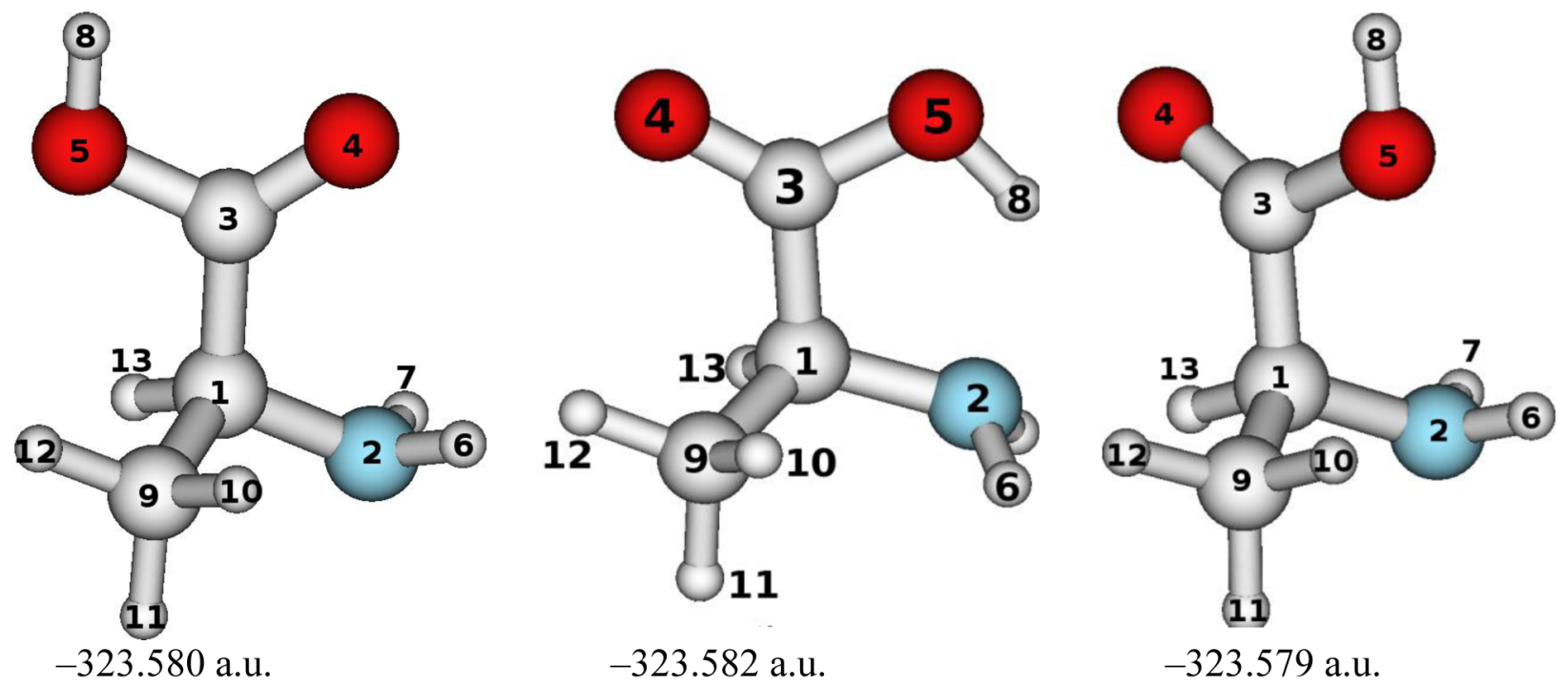

Fig. 1. Views and calculated total energies of neutral conformers of the alanine molecule: alanine I (left), alanine II (centre), and alanine III (right). 
The calculated bond lengths and bond orders of neutral and ionized alanine molecule conformers are listed in Tables 1 and 2.

According to the above results obtained for the neutral molecules, the weakest bonds are C1-C3 and $\mathrm{O} 5-\mathrm{H} 8$. Ionization of a parent molecule is most probably generated from the mixed $\sigma_{\mathrm{p}}$ orbital, which is the highest occupied molecular orbital. It includes $\mathrm{N} 2(0.41(2 \mathrm{pz}))$; O3(0.13(2pz)) electron moiety and its energy calculated by Koopmans' theorem is $6.59 \mathrm{eV}$ [22-24].

However, the experimental and calculated values as the difference of the energies of the neutral and ionized molecules for the first ionization energy of alanine are above this level and lie within 8.75$9.85 \mathrm{eV}[9,25,26]$. These results confirm very well known observations that the ionization energies calculated from the B3LYP/cc-pVTZ orbital energies are usually obtained with errors much larger than $2 \mathrm{eV}$. This implies that ionization of the alanine molecule could proceed from $\mathrm{HOMO}-1\left(\sigma_{\mathrm{p}} \mathrm{C} 1-\mathrm{O} 4-\mathrm{O} 5\right.$, $7.997 \mathrm{eV})$ and HOMO-2 $(\pi \mathrm{O} 4-\mathrm{O} 5,9.048 \mathrm{eV})$ orbitals as well. The decision is based on the investigation of the calculated molecular orbital because the current works show that the molecular orbital calculations performed within the B3LYP functional density approach are quite accurate and could be used for orientation aiming to foresee the charge localization and determine which orbital could be assigned to the specific fragmentation channel [27-29].

Thus, it is obvious that ionization of the alanine molecule involves the $\mathrm{NH}_{2} \mathrm{CHCOOH}$ group directly.

Table 1. Bond lengths of alanine conformers before and after ionization.

\begin{tabular}{c|c|c|c|c|c|c}
\hline Bonds & \multicolumn{2}{|c|}{ Alanine I } & \multicolumn{2}{c}{ Alanine II } & \multicolumn{2}{c}{ Alanine III } \\
\hline & $\begin{array}{c}\text { Bond length, } \\
\text { A neutral }\end{array}$ & $\begin{array}{c}\text { Bond length, } \\
\text { A ionized }\end{array}$ & $\begin{array}{c}\text { Bond length, } \\
\text { A neutral }\end{array}$ & $\begin{array}{c}\text { Bond length, } \\
\AA \text { ionized }\end{array}$ & $\begin{array}{c}\text { Bond length, } \\
\text { A neutral }\end{array}$ & $\begin{array}{c}\text { Bond length, } \\
\text { A ionized }\end{array}$ \\
\hline C1-N2 & 1.433 & 1.415 & 1.483 & 1.415 & 1.455 & 1.415 \\
\hline C1-C3 & 1.578 & 1.588 & 1.535 & 1.604 & 1.528 & 1.604 \\
\hline C1-C9 & 1.530 & 1.556 & 1.535 & 1.523 & 1.542 & 1.522 \\
\hline C1-H13 & 1.096 & 1.087 & 1.093 & 1.101 & 1.092 & 1.101 \\
\hline N2-H6 & 1.020 & 1.017 & 1.011 & 1.017 & 1.011 & 1.016 \\
\hline N2-H7 & 1.020 & 1.017 & 1.012 & 1.016 & 1.012 & 1.017 \\
\hline C3-O4 & 1.389 & 1.212 & 1.228 & 1.210 & 1.230 & 1.210 \\
\hline C3-O5 & 1.386 & 1.349 & 1.360 & 1.348 & 1.379 & 1.348 \\
\hline O5-H8 & 0.982 & 0.984 & 1.002 & 0.984 & 0.981 & 0.984 \\
\hline C9-H10 & 1.090 & 1.089 & 1.091 & 1.089 & 1.088 & 1.090 \\
\hline C9-H11 & 1.090 & 1.090 & 1.093 & 1.091 & 1.093 & 1.091 \\
\hline C9-H12 & 1.090 & 1.089 & 1.089 & 1.089 & 1.090 & 1.088 \\
\hline
\end{tabular}

Table 2. Bond orders of alanine conformers before and after ionization.

\begin{tabular}{c|c|c|c|c|c|c}
\hline Bonds & \multicolumn{2}{|c|}{ Alanine I } & \multicolumn{2}{c}{ Alanine II } & \multicolumn{2}{c}{ Alanine III } \\
\hline & $\begin{array}{c}\text { Bond order, } \\
\text { neutral }\end{array}$ & $\begin{array}{c}\text { Bond order, } \\
\text { ionized }\end{array}$ & $\begin{array}{c}\text { Bond order, } \\
\text { neutral }\end{array}$ & $\begin{array}{c}\text { Bond order, } \\
\text { ionized }\end{array}$ & $\begin{array}{c}\text { Bond order, } \\
\text { neutral }\end{array}$ & $\begin{array}{c}\text { Bond order, } \\
\text { ionized }\end{array}$ \\
\hline C1-N2 & 0.937 & 0.989 & 0.850 & 0.915 & 0.999 & 0.995 \\
\hline C1-C3 & 0.815 & 0.730 & 0.827 & 0.704 & 0.843 & 0.704 \\
\hline C1-C9 & 0.983 & 0.970 & 0.976 & 1.011 & 0.942 & 1.012 \\
\hline C1-H13 & 0.880 & 0.912 & 0.937 & 0.861 & 0.929 & 0.860 \\
\hline N2-H6 & 0.809 & 0.819 & 0.876 & 0.816 & 0.879 & 0.808 \\
\hline N2-H7 & 0.807 & 0.807 & 0.876 & 0.808 & 0.866 & 0.816 \\
\hline C3-O4 & 1.102 & 1.971 & 1.949 & 1.979 & 1.977 & 1.980 \\
\hline C3-O5 & 0.998 & 1.082 & 1.075 & 1.092 & 1.007 & 1.089 \\
\hline O5-H8 & 0.767 & 0.764 & 0.743 & 0.763 & 0.803 & 0.763 \\
\hline C9-H10 & 0.920 & 0.923 & 0.942 & 0.920 & 0.949 & 0.919 \\
\hline C9-H11 & 0.905 & 0.906 & 0.940 & 0.915 & 0.944 & 0.916 \\
\hline C9-H12 & 0.916 & 0.911 & 0.938 & 0.914 & 0.942 & 0.914 \\
\hline
\end{tabular}


As a result of ionization, the $\mathrm{C} 1-\mathrm{C} 3$ bond elongates for all isomeric structures, i. e. the probability of the molecular ion dissociation along this bond increases. Electron density redistribution due to the molecule ionization leads to a noticeable reduction of the C1-N2 bond length and to the increase of its strength forcing the carboxyl group atoms to approach each other. This testifies to the low probability of the alanine molecule dissociation channels related to the rupture of the skeleton carbon atom bonds with heteroatoms. It is also interesting to note that due to ionization of the above three conformers the $\mathrm{O} 5-\mathrm{H} 8$ and $\mathrm{C} 1-\mathrm{N} 2$ bond lengths become the same.

The area of the alanine molecule mass spectrum measured in our experiment at the $70 \mathrm{eV}$ electron energy (see Fig. 2) is generally close to that obtained in [9, 26, 30]. The main peculiarity of our mass spectrum is a larger intensity of the peak at $m / z=18$. Furthermore, presentation of this spectrum using a semi-logarithmic scale (see inset in Fig. 2) allowed specific features not discussed in the up-to-date papers to be revealed, i. e. the weak peak related to the doubly charged $\mathrm{m} / z=43.5$ ion and splitting of the $\mathrm{m} / z=18$ peak are observed clearly.
The peaks with $m=44,42,28,18$ Th are the most noticeable in the alanine mass spectrum. The absence of a clear parent molecular ion $\mathrm{C}_{3} \mathrm{H}_{7} \mathrm{NO}_{2}^{+}$peak (its intensity is about $0.2 \%$ of that for the maximal peak) indicates that probability of non-dissociative ionization for this molecule is negligible. The dominant peak in the experimental mass spectrum corresponds to the ion with the $m=44 \mathrm{Th}$ mass, i. e. to the $\mathrm{NH}_{2} \mathrm{CH}_{3} \mathrm{CH}^{+}$ion formed via a single rupture of the $\mathrm{C} 1-\mathrm{C} 3$ bond (see Fig. 1). Ab initio calculations of the fragmentation channels for the alanine cation find this channel to be energetically most favourable. These results coincide with those presented in [31]. The rupture of the $\mathrm{C} 1-\mathrm{C} 3$ bond results in the production of the $\mathrm{C}_{2} \mathrm{H}_{6} \mathrm{~N}$ and $\mathrm{CHO}_{2}$ fragments according to the following pathways:

$$
\mathrm{C}_{3} \mathrm{H}_{7} \mathrm{NO}_{2}+\mathrm{e} \rightarrow\left\{\begin{array}{l}
\mathrm{C}_{2} \mathrm{H}_{6} \mathrm{~N}^{+}+\mathrm{CHO}_{2}^{-}+\mathrm{e} \\
\mathrm{C}_{2} \mathrm{H}_{6} \mathrm{~N}^{+}+\mathrm{CHO}_{2}^{+}+3 \mathrm{e} \\
\mathrm{C}_{2} \mathrm{H}_{6} \mathrm{~N}^{+}+\mathrm{CHO}_{2}{ }^{+}+2 \mathrm{e} \\
\mathrm{C}_{2} \mathrm{H}_{6} \mathrm{~N}^{-}+\mathrm{CHO}_{2}{ }^{+}+\mathrm{e} \\
\mathrm{C}_{2} \mathrm{H}_{6} \mathrm{~N}^{0}+\mathrm{CHO}_{2}{ }^{+}+2 \mathrm{e}
\end{array}\right.
$$

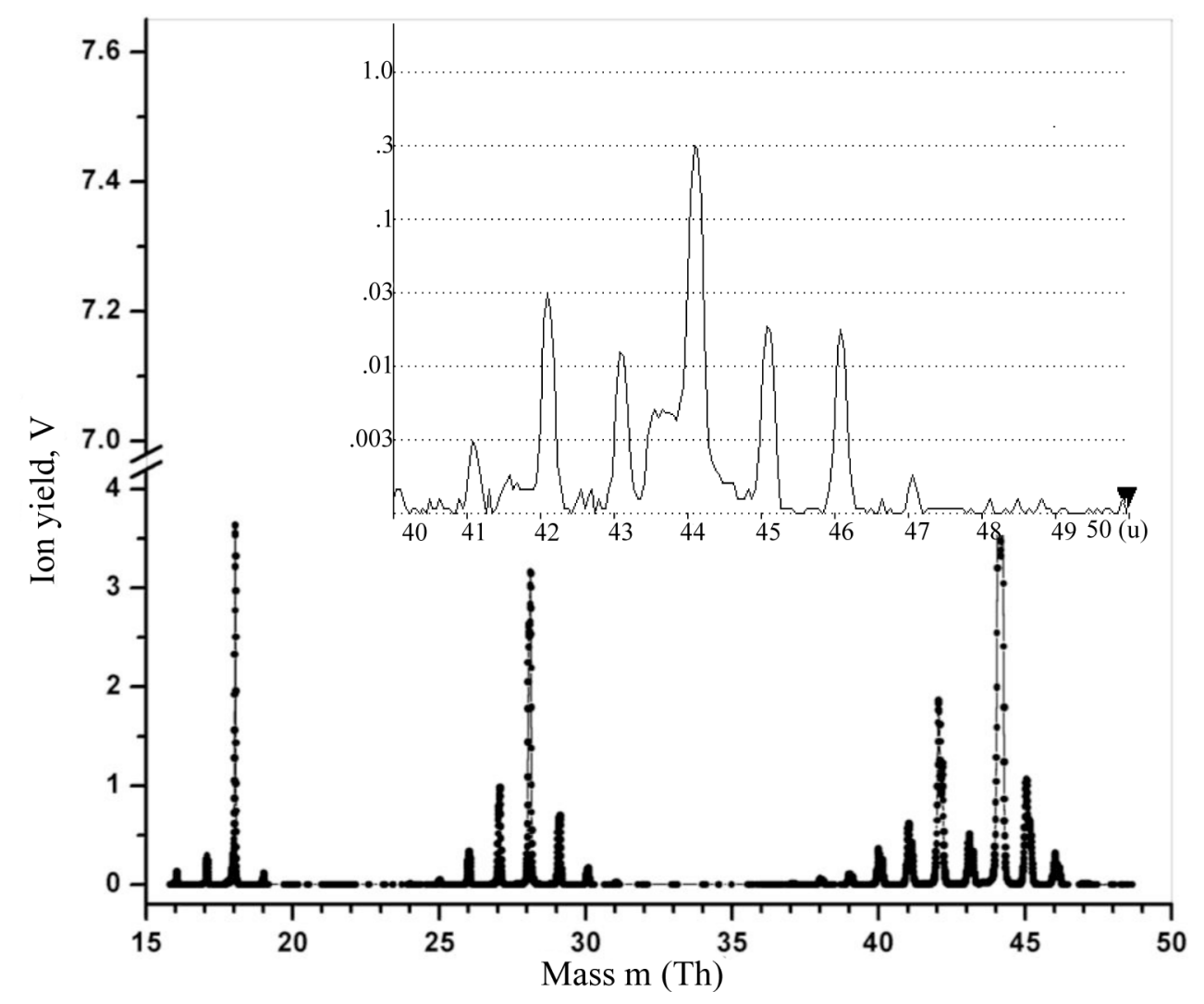

Fig. 2. Initial area of the DL $\alpha$-alanine molecule mass spectrum. 
The calculated appearance energies for the above fragments are listed in Tables 3 and 4 . The appearance energy $E_{\text {ap }}$ was calculated as $E_{\text {ap }}=\left|E_{\text {alan }}\right|-$ $\Sigma\left(E_{\mathrm{i}}\right) \mid$. Here, $E_{\text {alan }}$ is the total energy of the neutral alanine molecule, while $E_{\mathrm{i}}$ is the total energy of all fragments produced. This calculation does not take into account the activation energy of the molecular ion fragmentation.

Table 3. Calculated appearance energies (in $\mathrm{eV}$ ) for the $\mathrm{C}_{2} \mathrm{H}_{6} \mathrm{~N}$ and $\mathrm{CHO}_{2}$ fragments formed from the alanine I molecule.

\begin{tabular}{c|c|c|c}
\hline $\begin{array}{c}\mathrm{C}_{2} \mathrm{H}_{6} \mathrm{~N} \\
=44 \mathrm{Th}) \\
\text { charge }\end{array}$ & $\begin{array}{c}\mathrm{CHO}_{2} \\
(m=45 \mathrm{Th}) \\
\text { charge }\end{array}$ & $\begin{array}{c}\text { Alanine } \\
\text { molecule } \\
\text { geometry not } \\
\text { changed }^{*}\end{array}$ & $\begin{array}{c}\text { Alanine } \\
\text { molecule } \\
\text { geometry }_{\text {changed }}^{* *}\end{array}$ \\
\hline 1 & -1 & 10.07 & 7.58 \\
\hline 1 & 1 & 22.69 & 17.61 \\
\hline 1 & 0 & 11.40 & 9.12 \\
\hline-1 & 1 & 16.60 & 13.16 \\
\hline 0 & 1 & 15.29 & 12.08 \\
\hline
\end{tabular}

* Alanine molecule geometry not changed means that the single point energy calculation of fragments, taking into account the geometry of a certain part of the alanine molecule, was performed.

** Alanine molecule geometry changed indicates that the equilibrium geometry structure of alanine molecule fragments is investigated.

Table 4. Calculated appearance energies (in $\mathrm{eV}$ ) for the $\mathrm{C}_{2} \mathrm{H}_{6} \mathrm{~N}$ and $\mathrm{CHO}_{2}$ fragments formed from the alanine II molecule.

\begin{tabular}{c|c|c|c}
\hline $\begin{array}{c}\mathrm{C}_{2} \mathrm{H}_{6} \mathrm{~N} \\
\text { charge } \\
\text { ch }\end{array}$ & $\begin{array}{c}\mathrm{CHO}_{2} \\
(m=45 \mathrm{Th}) \\
\text { charge }\end{array}$ & $\begin{array}{c}\text { Alanine } \\
\text { molecule } \\
\text { geometry } \\
\text { not changed }\end{array}$ & $\begin{array}{c}\text { Alanine } \\
\text { molecule } \\
\text { geometry }^{*} \\
\text { changed }\end{array}$ \\
\hline 1 & -1 & 10.92 & 7.69 \\
\hline 1 & 1 & 22.17 & 17.65 \\
\hline 1 & 0 & 11.64 & 9.04 \\
\hline-1 & 1 & 15.78 & 13.20 \\
\hline 0 & 1 & 14.60 & 12.12 \\
\hline${ }^{*}{ }^{* *}$ see explanatory notes in Table 3.
\end{tabular}

As pointed out, the main structural differences between alanine I and alanine III disappears when these molecules are ionized. Such behaviour of alanine conformers allows the appearance energy calculations to be performed for two conformers only, i. e. for alanine I and II molecules.

The most energetically favourable channels of the $\mathrm{C}_{2} \mathrm{H}_{6} \mathrm{~N}^{+}$cation formation correspond to pathways
(1) and (3). Experimental results indicate that the appearance energy for the $\mathrm{C}_{2} \mathrm{H}_{6} \mathrm{~N}^{+}$fragment ion under the electron impact ionization of the gas phase L-alanine determined from the measured ion efficiency curves is $9.10 \pm 0.05 \mathrm{eV}$ [9], while that of the DL-alanine measured by us is $9.30 \pm 0.1 \mathrm{eV}$. In the photoionization experiment [26], the appearance energy for this fragment ion is $9.05 \pm 0.10 \mathrm{eV}$. These results allow us to conclude which of the channels is more probable for the conformers of the alanine molecule, and this agrees with the results of other authors. It should be noted that the calculated value of the appearance energy for the $\mathrm{C}_{2} \mathrm{H}_{6} \mathrm{~N}^{+}$cation from the L-alanine molecule listed in [9] is $9.51 \mathrm{eV}$ and is larger than that determined experimentally. The calculated values of the appearance energies for this fragment formed from alanine $\mathrm{I}(9.12 \mathrm{eV})$ and alanine II $(9.04 \mathrm{eV})$ coincide perfectly with the thermochemical value of $9.12 \mathrm{eV}$ calculated based on the data on the heat of formation and with the results presented in [26] as well as with those obtained experimentally.

We have checked the possibility of formation of the $\mathrm{CO}_{2}^{+}$ion as a probable product of dissociative ionization of the alanine molecule. The calculated results indicate that formation of this ion is energetically non-favourable because the appearance energy for this fragment is approximately twice larger than that for the $\mathrm{C}_{2} \mathrm{H}_{6} \mathrm{~N}^{+}$fragment. It should be mentioned that the appearance energy for the $\mathrm{CO}_{2}^{+}$ion presented in [9] is by $3 \mathrm{eV}$ smaller than the value obtained by us as the smallest appearance energy of the $\mathrm{CO}_{2}^{+}$fragment for the DL-alanine molecule. Summarizing the data previously mentioned, it is possible to conclude that the peak at $m=44 \mathrm{Th}$ in the experimental mass spectrum could be attributed to the formation of the $\mathrm{C}_{2} \mathrm{H}_{6} \mathrm{~N}^{+}$fragment.

It should be noted that in case of the $\mathrm{C} 1-\mathrm{C} 3$ bond dissociation in the initial molecule the complementary fragment with the 45 Th mass is produced. The calculated appearance energy for this ion is $12.08 \mathrm{eV}$ for the alanine I molecule and $12.12 \mathrm{eV}$ for the alanine II molecule. We predict that the presence of the hydrogen bond $\mathrm{O} 4 \cdots \mathrm{H} 8$ in the alanine I and alanine III molecules could favour this fragment stability during the $\mathrm{C} 1-\mathrm{C} 3$ bond dissociation.

In the mass range of 40-50 Th (see Fig. 3), a very small peak at $m=42$ Th was observed experimentally. This peak may be attributed to the presence of the $\mathrm{CH}_{3} \mathrm{CHN}^{+}$(or $\mathrm{C}_{2} \mathrm{H}_{4} \mathrm{~N}^{+}$) ion, although 


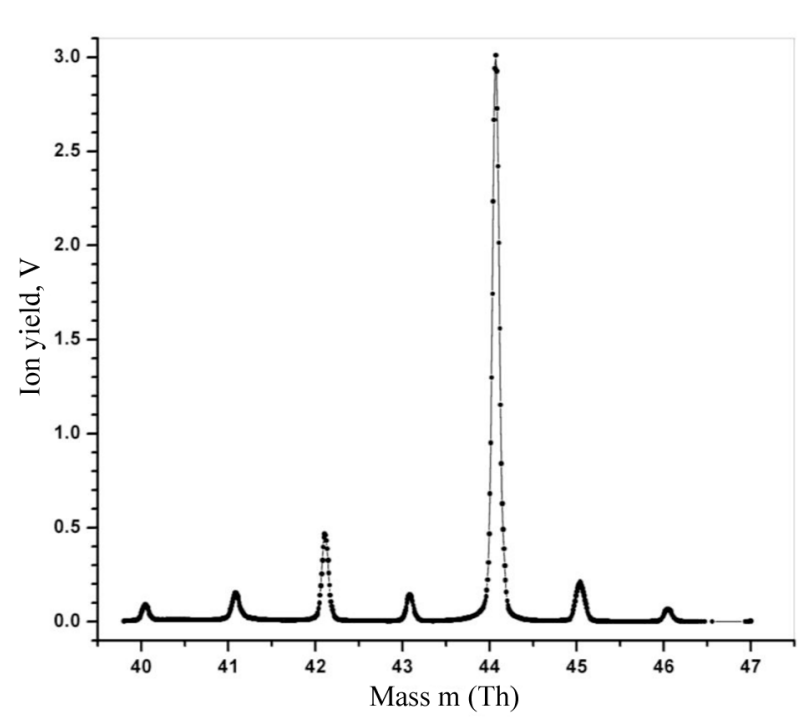

Fig. 3. Area of the DL-alanine molecule mass spectrum in the 40-50 Th mass region.

Jochims et al. 26] and Ipolyi et al. [9] identified this fragment as $\mathrm{NH}_{2} \mathrm{CH}_{2}=\mathrm{C}^{+}$and $\mathrm{CH}_{3} \mathrm{C} \equiv \mathrm{NH}^{+}$, respectively. Our decision is based on the analysis of the bond order of the neutral conformers that indicates that the $\mathrm{C} 1-\mathrm{C} 3, \mathrm{~N} 2-\mathrm{H} 7$, and N2-H6 bonds are weaker than other $\mathrm{C}-\mathrm{H}$ bonds (Table 2). On the other hand, we suggest another structure for this fragment not mentioned among possible structures calculated for this stoichiometry.

Hence, the above fragments may be produced according to the following pathways:

$$
\mathrm{C}_{3} \mathrm{H}_{7} \mathrm{NO}_{2}+\mathrm{e} \rightarrow\left\{\begin{array}{l}
\mathrm{C}_{2} \mathrm{H}_{4} \mathrm{~N}^{+}+\left(\mathrm{H}+\mathrm{H}+\mathrm{CHO}_{2}\right)^{-}+\mathrm{e}, \\
\mathrm{C}_{2} \mathrm{H}_{4} \mathrm{~N}^{+}+\left(\mathrm{H}+\mathrm{H}+\mathrm{CHO}_{2}\right)^{+}+3 \mathrm{e}, \\
\mathrm{C}_{2} \mathrm{H}_{4} \mathrm{~N}^{+}+\left(\mathrm{H}+\mathrm{H}+\mathrm{CHO}_{2}\right)^{0}+2 \mathrm{e} .
\end{array}\right.
$$

The results of the appearance energy studies for this fragment indicate the pathway (6) to be more favourable for alanine I and alanine II (Tables 5, 6). Theoretical values of 10.08 and $10.18 \mathrm{eV}$ obtained for alanine I and alanine II, respectively, coincide with the experimental one of $(9.87 \pm 0.1 \mathrm{eV})$ [9] proving the assumption that alanine conformers could be ruptured producing the $\mathrm{C}_{2} \mathrm{H}_{4} \mathrm{~N}^{+}$ionic fragment via the ion pair formation according to the pathway (6). The results of the geometry optimization of the $\mathrm{H}+\mathrm{H}+\mathrm{CHO}_{2}$ charged compound indicate that the neutral $\mathrm{H}_{2}$ molecule could be formed, although in the present study the above results are of no importance.
Table 5. Calculated appearance energies (in $\mathrm{eV}$ ) for the $\mathrm{C}_{2} \mathrm{H}_{4} \mathrm{~N}$ and $\left(\mathrm{H}+\mathrm{H}+\mathrm{CHO}_{2}\right)$ fragments formed from the alanine I molecule.

\begin{tabular}{c|c|c|c}
\hline $\begin{array}{c}\mathrm{C}_{2} \mathrm{H}_{4} \mathrm{~N} \\
=42 \mathrm{Th}) \\
\text { charge }\end{array}$ & $\begin{array}{c}\mathrm{H}+\mathrm{H}+\mathrm{CHO}_{2} \\
\text { charge }\end{array}$ & $\begin{array}{c}\text { Alanine } \\
\text { molecule } \\
\text { geometry } \\
\text { not changed }\end{array}$ & $\begin{array}{c}\text { Alanine } \\
\text { molecule } \\
\text { geometry } \\
\text { changed }\end{array}$ \\
\hline 1 & -1 & 19.68 & 10.08 \\
\hline 1 & 0 & 20.87 & 11.74 \\
\hline 1 & 1 & 31.26 & 20.18 \\
\hline${ }^{*},{ }^{* *}$ see explanatory notes in Table 3.
\end{tabular}

Table 6. Calculated appearance energies (in $\mathrm{eV}$ ) for the $\mathrm{C}_{2} \mathrm{H}_{4} \mathrm{~N}$ and $\left(\mathrm{H}+\mathrm{H}+\mathrm{CHO}_{2}\right)$ fragments formed from the alanine II molecule.

\begin{tabular}{c|c|c|c}
\hline $\begin{array}{c}\mathrm{C}_{2} \mathrm{H}_{4} \mathrm{~N} \\
=42 \mathrm{Th}) \\
\text { charge }\end{array}$ & $\begin{array}{c}\mathrm{H}+\mathrm{H}+\mathrm{CHO}_{2} \\
\text { charge }\end{array}$ & $\begin{array}{c}\text { Alanine } \\
\text { molecule } \\
\text { geometry } \\
\text { not changed }\end{array}$ & $\begin{array}{c}\text { Alanine } \\
\text { molecule } \\
\text { geometry }^{*}\end{array}$ \\
changed $^{* *}$
\end{tabular}

The appearance energies for the $\mathrm{C}_{2} \mathrm{H}_{4} \mathrm{~N}^{+}$ions with different structural conformers calculated in the present study are closer to the experimental value than the $a b$ initio result $(10.87 \mathrm{eV})$ presented in [9], where it was stated that the $\mathrm{CH}_{3} \mathrm{CNH}^{+}$ ion is formed via the following reaction process: $\mathrm{C}_{3} \mathrm{H}_{7} \mathrm{NO}_{2}^{+} \rightarrow \mathrm{CH}_{3} \mathrm{CNH}^{+}+\mathrm{HCO}^{-}+\mathrm{H}_{2} \mathrm{O}$. Note that in both schemes the $\mathrm{C}_{2} \mathrm{H}_{4} \mathrm{~N}^{+}$ion appears in the case of an ion pair formation. Thus, the mechanism of the $\mathrm{C}_{2} \mathrm{H}_{4} \mathrm{~N}^{+}$ion production includes the detachment of a carboxyl group from the initial molecule accompanied by the molecular hydrogen formation according to the pathway (6) rather than the disintegration process of the $\mathrm{COOH}$ group and the water molecule elimination as suggested in [9].

As emphasized above, the present calculations result in the values that coincide well with the experimental ones obtained by us. Furthermore, it should be noted that optimization results indicate changeability of the initial $\mathrm{CH}_{3} \mathrm{CHN}^{+}$ion geometrical structure. The fragment $\mathrm{CH}_{3} \mathrm{CHN}^{+}$transforms to $\mathrm{CH}_{3} \mathrm{NCH}^{+}$at its equilibrium point. We started optimization from the $\mathrm{CH}_{3} \mathrm{CNH}^{+}$structure and finally obtained the $\mathrm{CH}_{3}-\mathrm{N}-\mathrm{CH}^{+}$structure. Geometrical structures of the $\mathrm{C}_{2} \mathrm{H}_{4} \mathrm{~N}^{+}$ion before and after optimization are shown in Fig. 4 . 

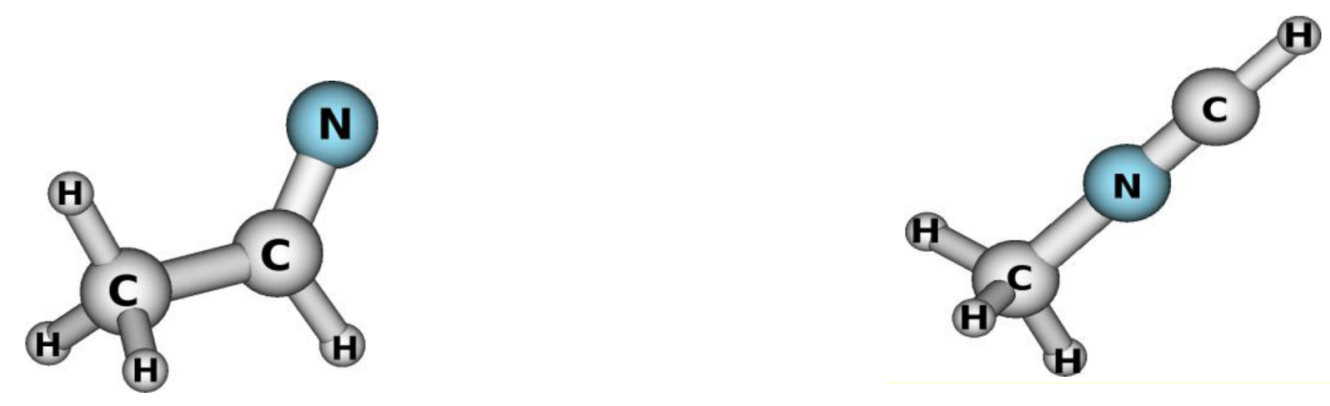

Fig. 4. Views of the $\mathrm{CH}_{3} \mathrm{CHN}^{+}$fragment when alanine is ruptured (left) and at the equilibrium point (right).

The mechanism of the structural change during the formation of the above ion could take place via the intermediate cyclic structure of the dehydrated ethylene imine according the scheme given below:<smiles>C[NH2+]C[C@@H]1C[C@H]2CC[NH+]1C2</smiles>

This intermediate structure is possible to be obtained when analysing the optimization process. The bond order analysis indicates that in the $\mathrm{C}_{2} \mathrm{H}_{4} \mathrm{~N}^{+}$positive ion structure the double bonds are formed between both $\mathrm{N}$ and $\mathrm{C}$ atoms, while the bond order between $\mathrm{C}-\mathrm{C}$ atoms is 0.846 . Thus, this bond is the weakest one in the intermediate cyclic structure and the above bond rupture is possible. In the obtained structure, the $\mathrm{C} 1$ atom undergoes, obviously, the $s p$-hybridization.

Based on the results described above, we state that the pathway

$$
\begin{aligned}
& \mathrm{C}_{3} \mathrm{H}_{7} \mathrm{NO}_{2}+\mathrm{e} \rightarrow \mathrm{C}_{2} \mathrm{H}_{4} \mathrm{~N}^{+}+\left(\mathrm{H}+\mathrm{H}+\mathrm{CHO}_{2}\right)^{-}+\mathrm{e} \rightarrow \\
& \rightarrow \mathrm{CH}_{3} \mathrm{NCH}^{+}+\left(\mathrm{H}_{2}+\mathrm{CHO}_{2}\right)^{-}+\mathrm{e}
\end{aligned}
$$

is more probable than any other mentioned in [9].

The ion with the $m=28$ Th mass is the second intensity-related peak in the parent molecule spectrum and is accompanied by the satellite peaks with the $m=27 \mathrm{Th}$ and $m=29 \mathrm{Th}$ masses. The area of the DL-alanine molecule mass spectrum in the 26.5-29.5 Th region presented in the semi-logarithmic scale is shown in Fig. 5 .
It is obvious that all three peaks in Fig. 5 have a double-headed shape, so at least two ions may contribute to each peak. As to the $m=27 \mathrm{Th}$ peak, Jochims et al. [26] assigned it to the $\mathrm{C}_{2} \mathrm{H}_{3}^{+}$ion rather than to the $\mathrm{HCN}^{+}$one and confirmed this conclusion by the $\alpha$-alanine-d3 electron impact mass spectrum. Our spectra show the presence of the two of these isobaric ions with nearly close intensities but some preference is given to the $\mathrm{C}_{2} \mathrm{H}_{3}^{+}$ ion.

A double-headed peak with the $m=29$ Th mass is due to the two components and consists of the $\mathrm{HCO}^{+}$and $\mathrm{NH}_{2} \mathrm{CH}^{+}$ions with some preference being given to the $\mathrm{HCO}^{+}$ion. It should be noted that deuteration of the $\alpha$-alanine molecule does not help to choose between these two possible assignments [26], and our results show that both ions are formed in the collision event.

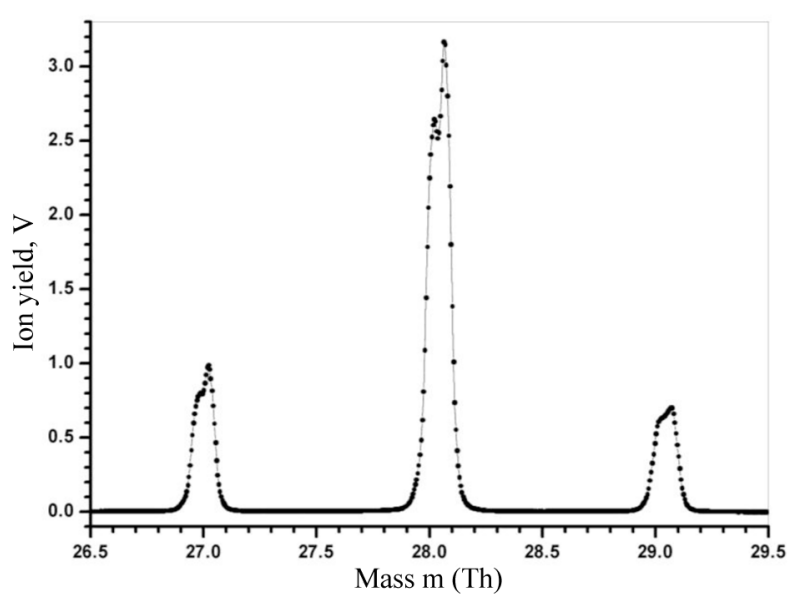

Fig. 5. Area of the DL-alanine molecule mass spectrum in the 26.5-29.5 Th mass region. 
The $m=28$ Th ion is an intense fragment in the alanine spectrum and may have the following gross formulae: $\mathrm{CH}_{2} \mathrm{~N}, \mathrm{C}_{2} \mathrm{H}_{4}$, and $\mathrm{CO}$. Jochims et al. [26], Ipolyi et al. [9], and Bari et al. [32] assigned it exceptionally to the $\mathrm{HCNH}^{+}$ion, but Lago et al. [33] identified this peak as consisting of the $\mathrm{HCNH}^{+}$ and $\mathrm{CO}^{+}$ions. In our spectrum, only two distinct peaks arise in the vicinity of the $28 \mathrm{Th}$ mass.

A comparison of the stability of the $\mathrm{C}_{2} \mathrm{H}_{4}^{+}$, $\mathrm{CH}_{2} \mathrm{~N}^{+}$, and $\mathrm{CO}^{+}$ions (i. e. comparison of calculated binding energies per atom in $\mathrm{eV}$ ) allows us to conclude that $\mathrm{C}_{2} \mathrm{H}_{4}^{+}$is more stable than $\mathrm{CO}^{+}$and $\mathrm{CH}_{2} \mathrm{~N}^{+}$. However, the binding energy per atom for $\mathrm{C}_{2} \mathrm{H}_{4}^{+}$is by $0.31 \mathrm{eV}$ larger than that for $\mathrm{CH}_{2} \mathrm{~N}^{+}$and by $1.23 \mathrm{eV}$ larger than that for the $\mathrm{CO}^{+}$ion. In case of methionine [34], we have shown that the formation of the $\mathrm{CO}^{+}$ion is energetically less probable than that of the $\mathrm{C}_{2} \mathrm{H}_{4}^{+}$and $\mathrm{CH}_{2} \mathrm{~N}^{+}$ions.

As for the calculated appearance energies of these fragments (see Tables 7-10) it should be mentioned that they are somewhat different. Thus, in case of the $\mathrm{C}_{2} \mathrm{H}_{4}^{+}$ion, the appearance energy is in both cases under the study smaller by more than $4 \mathrm{eV}$ if the alanine molecule geometry was not changed. However, if the equilibrium geometry was reached, the results became a bit contradictory. For the ion pair formation, the appearance of the $\mathrm{CH}_{2} \mathrm{~N}^{+}$ion seems to be more probable. When the positively charged ion and the neutral molecule are formed, the appearance energy values become very close, so both $\mathrm{C}_{2} \mathrm{H}_{4}^{+}$ and $\mathrm{CH}_{2} \mathrm{~N}^{+}$ions might arise. Thus, we may conclude that two isobaric ions peaks with the $m=28$ Th mass in the experimental spectra belong to the $\mathrm{C}_{2} \mathrm{H}_{4}{ }^{+}$and $\mathrm{CH}_{2} \mathrm{~N}^{+}$ions and the channel of the $\mathrm{C}_{2} \mathrm{H}_{4}^{+}$ion formation is more efficient at the $70 \mathrm{eV}$ collision energy than that of the $\mathrm{CH}_{2} \mathrm{~N}^{+}$ion.

The positively charged $\mathrm{CH}_{2} \mathrm{~N}^{+}$ion could be produced differently: (i) at a simultaneous break of several simple bonds, (ii) in the two-stage process via dissociation of the glycyl radical cation after elimination of a methyl group, and (iii) due to the loss of $\mathrm{H}_{2}$ from the primarily formed $\mathrm{NH}_{2} \mathrm{CH}_{2}^{+}$.

It is necessary to emphasize that in our previous papers [35, 36] the glycine and the methionine molecule mass spectra revealed diffuse peaks at about $m^{*} \sim 26.1$ Th corresponding to the transition $30 \rightarrow 28$ being accompanied by the detachment of a neutral fragment with $m=2 \mathrm{Th}$, i. e. the secondary fragmentation of the $\mathrm{CH}_{4} \mathrm{~N}^{+}$ion occurred. However, in the case of alanine, this dis-
Table 7. Calculated appearance energies (in $\mathrm{eV}$ ) for the $\mathrm{C}_{2} \mathrm{H}_{4}$ and $\left(\mathrm{NH}_{2}+\mathrm{COOH}\right)$ fragments formed from the alanine I molecule.

\begin{tabular}{|c|c|c|c|}
\hline $\begin{array}{c}\mathrm{C}_{2} \mathrm{H}_{4} \\
(m=28 \mathrm{Th}) \\
\text { charge }\end{array}$ & $\begin{array}{c}\mathrm{NH}_{2}+\mathrm{COOH} \\
\text { charge }\end{array}$ & $\begin{array}{c}\text { Alanine } \\
\text { molecule } \\
\text { geometry } \\
\text { not changed }\end{array}$ & $\begin{array}{l}\text { Alanine } \\
\text { molecule } \\
\text { geometry } \\
\text { changed }^{* *}\end{array}$ \\
\hline 1 & -1 & 15.97 & 13.44 \\
\hline 1 & 0 & 17.89 & 11.80 \\
\hline
\end{tabular}

Table 8. Calculated appearance energies (in $\mathrm{eV}$ ) for the $\mathrm{C}_{2} \mathrm{H}_{4}$ and $\left(\mathrm{NH}_{2}+\mathrm{CHO}_{2}\right)$ fragments formed from the alanine II molecule.

\begin{tabular}{c|c|c|c}
\hline $\begin{array}{c}\mathrm{C}_{2} \mathrm{H}_{4} \\
\text { charge } \\
\text { charg }\end{array}$ & $\begin{array}{c}\mathrm{NH}_{2}+\mathrm{COOH} \\
\text { charge }\end{array}$ & $\begin{array}{c}\text { Alanine } \\
\text { molecule } \\
\text { geometry } \\
\text { not changed }\end{array}$ & $\begin{array}{c}\text { Alanine } \\
\text { molecule } \\
\text { geometry } \\
\text { changed }\end{array}$ \\
\hline 1 & -1 & 15.38 & 12.08 \\
\hline 1 & 0 & 17.31 & 12.21 \\
\hline 1 & 1 & 26.30 \\
\hline
\end{tabular}

Table 9. Calculated appearance energies (in $\mathrm{eV}$ ) for the $\mathrm{CH}_{2} \mathrm{~N}$ and $\left(\mathrm{COOH}+\mathrm{H}+\mathrm{CH}_{3}\right)$ fragments formed from the alanine I molecule.

\begin{tabular}{|c|c|c|c|}
\hline $\begin{array}{c}\mathrm{C}-\mathrm{NH}_{2} \\
(m=28 \mathrm{Th}) \\
\text { harge }\end{array}$ & $\begin{array}{c}\mathrm{COOH}+\mathrm{H}+\mathrm{CH}_{3} \\
\text { charge }\end{array}$ & $\begin{array}{c}\text { Alanine } \\
\text { molecule } \\
\text { geometry } \\
\text { not changed }\end{array}$ & $\begin{array}{l}\text { Alanine } \\
\text { molecule } \\
\text { geometry } \\
\text { changed }^{* *}\end{array}$ \\
\hline 1 & -1 & 21.08 & 9.98 \\
\hline 1 & 0 & 21.69 & 12.41 \\
\hline 1 & 1 & 31.92 & 19.51 \\
\hline
\end{tabular}

Table 10. Calculated appearance energies (in $\mathrm{eV}$ ) for the $\mathrm{CH}_{2} \mathrm{~N}$ and $\left(\mathrm{COOH}+\mathrm{H}+\mathrm{CH}_{3}\right)$ fragments formed from the alanine II molecule.

\begin{tabular}{c|c|cc}
\hline $\begin{array}{c}\mathrm{C}-\mathrm{NH}_{2} \\
(m=28 \mathrm{Th}) \\
\text { charge }\end{array}$ & $\begin{array}{c}\mathrm{COOH}+\mathrm{H}+\mathrm{CH}_{3} \\
\text { charge }\end{array}$ & $\begin{array}{c}\text { Alanine } \\
\text { molecule } \\
\text { geometry } \\
\text { not changed }\end{array}$ & $\begin{array}{c}\text { Alanine } \\
\text { molecule } \\
\text { geometry } \\
\text { changed }\end{array}$ \\
\hline 1 & -1 & 19.92 & 8.94 \\
\hline 1 & 0 & 21.09 & 12.45 \\
\hline 1 & 1 & 31.29 & 19.55 \\
\hline \multicolumn{4}{r}{${ }^{* *}$ see explanatory notes in Table 3. }
\end{tabular}

sociation channel was not observed by us. Thus, the dehydration process according to the scheme $\mathrm{CH}_{4} \mathrm{~N}^{+} \rightarrow(\mathrm{H}+\mathrm{H})^{0}+\mathrm{CH}_{2} \mathrm{~N}^{+}$is not realized in the electron-impact-induced alanine molecule fragmentation. 
We have calculated the $\mathrm{CH}_{2} \mathrm{~N}^{+}$ion production from different conformers of alanine with different bonds being ruptured. When the equilibrium geometry structure of the alanine molecule fragments is taken into account, the smallest appearance energies were obtained when $\mathrm{CH}_{2} \mathrm{~N}^{+}$was formed according to the following general pathways:

$$
\mathrm{C}_{3} \mathrm{H}_{7} \mathrm{NO}_{2}+\mathrm{e} \rightarrow\left\{\begin{array}{l}
\mathrm{CH}_{2} \mathrm{~N}^{+}+\left(\mathrm{COOH}+\mathrm{H}+\mathrm{CH}_{3}\right)^{-}+\mathrm{e}, \quad(9) \\
\mathrm{CH}_{2} \mathrm{~N}^{+}+\left(\mathrm{COOH}+\mathrm{H}+\mathrm{CH}_{3}\right)^{0}+2 \mathrm{e},(10) \\
\mathrm{CH}_{2} \mathrm{~N}^{+}+\left(\mathrm{COOH}+\mathrm{H}+\mathrm{CH}_{3}\right)^{+}+3 \mathrm{e} .(11)
\end{array}\right.
$$

The calculated energies required to produce the above fragments are listed in Tables 7 and 8 .

It was mentioned in [9] that the ion production efficiency curve for the alanine molecule fragment with the $m=28$ Th mass exhibits two distinct thresholds at 10.85 and $12.8 \mathrm{eV}$. In [26], the $\mathrm{CH}_{2} \mathrm{~N}^{+}$ion-yield curve exhibits an initial onset at $9.00 \pm 1 \mathrm{eV}$ and a sharp rise in the signal at $12.35 \mathrm{eV}$, and this, according to the point of view of the authors, was considered to be a second onset energy attributed to the loss of $\mathrm{H}_{2}$ from the primarily formed $\mathrm{NH}_{2} \mathrm{CH}_{2}{ }^{+}$. The analysis of the results allows us to predict that the thresholds at the $\mathrm{NH}_{2} \mathrm{CH}_{2}^{+}$fragment appearance from alanine I and alanine II could be close to those mentioned above. It implies that the stepwise structure of this ion yield curve may be due not only to the different pathways of the parent molecule dissociation but also to the change of the charge of the complementary particles produced. Thus, according to our calculations, the process corresponding to the pathway (9) with ion pair production is energetically more favourable.

According to the qualitative mass spectrometry theory, where the direction of fragmentation of the molecule under study is defined by the stability of the fragments produced, the formation of the $\mathrm{CH}_{2} \mathrm{~N}^{+}$ion seems to be the most probable according to the following pathways:

$$
\begin{aligned}
& \mathrm{C}_{3} \mathrm{H}_{7} \mathrm{NO}_{2}^{+} \rightarrow \mathrm{CH}_{2} \mathrm{~N}^{+}+\left(\mathrm{CH}_{3}+\mathrm{CO}_{2}+2 \mathrm{H}\right)^{\cdot} \rightarrow \\
& \rightarrow \mathrm{CH}_{2} \mathrm{~N}^{+}+\left(\mathrm{CH}_{3}^{\cdot}+\mathrm{CO}_{2}+\mathrm{H}_{2}\right)
\end{aligned}
$$

and

$$
\mathrm{C}_{3} \mathrm{H}_{7} \mathrm{NO}_{2}^{+} \rightarrow \mathrm{CH}_{2} \mathrm{~N}^{+}+\left(\mathrm{CH}_{3}+\mathrm{CO}+(\mathrm{OH}+\underbrace{\mathrm{H}}_{\mathrm{H}_{2}})\right)(13)
$$

Thus, the fragments that may be produced in this case are the stable molecules and the radical. In our calculations, both these reactions were studied, but, unfortunately, the last process appeared impossible to be calculated from the very beginning (i. e. when parts of the alanine molecule were used) because there was some intermediate reaction resulting in the formation of the $\mathrm{CO}$ and $\mathrm{OH}$ fragments.

The calculated appearance energies for the case of reaction (12) are listed in Tables 11, 12 (see also Tables 13, 13).

Table 11. Calculated appearance energies (in $\mathrm{eV}$ ) for the $\mathrm{CH}_{2} \mathrm{~N}$ and $\mathrm{CH}_{3}+\mathrm{CO}_{2}+2 \mathrm{H}$ fragments formed from the alanine I molecule.

\begin{tabular}{c|c|c|c}
\hline $\begin{array}{c}\mathrm{CH}_{2} \mathrm{~N} \\
(m=28 \mathrm{Th}) \\
\text { charge }\end{array}$ & $\begin{array}{c}\mathrm{CH}_{3}+ \\
\mathrm{CO}_{2}+2 \mathrm{H} \\
\text { charge }\end{array}$ & $\begin{array}{c}\text { Alanine } \\
\text { molecule } \\
\text { geometry } \\
\text { not changed }\end{array}$ & $\begin{array}{c}\text { Alanine } \\
\text { molecule } \\
\text { geometry } \\
\text { changed }\end{array}$ \\
\hline 1 & -1 & 15.21 & 0.36 \\
\hline 1 & 0 & 15.50 & 3.87 \\
\hline 1 & 1 & 28.64 & 11.83 \\
\hline${ }^{*},{ }^{* *}$ see explanatory notes in Table 3.
\end{tabular}

Table 12. Calculated appearance energies (in $\mathrm{eV}$ ) for the $\mathrm{CH}_{2} \mathrm{~N}$ and $\mathrm{CH}_{3}+\mathrm{CO}_{2}+2 \mathrm{H}$ fragments formed from the alanine II molecule.

\begin{tabular}{|c|c|c|c|}
\hline $\begin{array}{c}\text { HC-NH } \\
(m=28 \mathrm{Th}) \\
\text { charge }\end{array}$ & $\begin{array}{c}\mathrm{COOH}+\mathrm{H}+\mathrm{CH}_{3} \\
\text { charge }\end{array}$ & $\begin{array}{c}\text { Alanine } \\
\text { molecule } \\
\text { geometry } \\
\text { not changed }\end{array}$ & $\begin{array}{c}\text { Alanine } \\
\text { molecule } \\
\text { geometry } \\
\text { changed }^{* *}\end{array}$ \\
\hline 1 & -1 & 20.22 & 9.48 \\
\hline 1 & 0 & 20.89 & 12.12 \\
\hline 1 & 1 & 31.19 & 19.50 \\
\hline
\end{tabular}

\begin{tabular}{c|c|c|c}
\hline $\begin{array}{c}\mathrm{CH}_{2} \mathrm{~N} \\
(m=28 \mathrm{Th}) \\
\text { charge }\end{array}$ & $\begin{array}{c}\mathrm{CH}_{3}+ \\
\mathrm{CO}_{2}+2 \mathrm{H} \\
\text { charge }\end{array}$ & $\begin{array}{c}\text { Alanine } \\
\text { molecule } \\
\text { geometry } \\
\text { not changed }\end{array}$ & $\begin{array}{c}\text { Alanine } \\
\text { molecule } \\
\text { geometry } \\
\text { changed }\end{array}$ \\
\hline 1 & -1 & 18.40 & 0.95 \\
\hline 1 & 0 & 19.79 & 3.59 \\
\hline 1 & 1 & 30.75 & 10.97 \\
\hline${ }^{*},{ }^{* *}$ see explanatory notes in Table 3.
\end{tabular}

Table 13. Calculated appearance energies (in $\mathrm{eV}$ ) for the $\mathrm{CH}_{2} \mathrm{~N}$ and $\left(\mathrm{COOH}+\mathrm{H}+\mathrm{CH}_{3}\right)$ fragments formed from the alanine I molecule. 
Table 14. Calculated appearance energies (in eV) for the $\mathrm{CH}_{2} \mathrm{~N}$ and $\left(\mathrm{COOH}+\mathrm{H}+\mathrm{CH}_{3}\right)$ fragments formed from the alanine I molecule.

\begin{tabular}{c|c|c|c}
\hline $\begin{array}{c}\mathrm{HC}-\mathrm{NH} \\
(m=28 \mathrm{Th}) \\
\text { charge }\end{array}$ & $\begin{array}{c}\mathrm{COOH}+\mathrm{H}+\mathrm{CH}_{3} \\
\text { charge }\end{array}$ & $\begin{array}{c}\text { Alanine } \\
\text { molecule } \\
\text { geometry }_{\text {not changed }}^{*}\end{array}$ & $\begin{array}{c}\text { Alanine } \\
\text { molecule } \\
\text { geometry }_{\text {changed }^{* *}}\end{array}$ \\
\hline 1 & -1 & 21.32 & 8.94 \\
\hline 1 & 0 & 22.66 & 12.45 \\
\hline 1 & 1 & 32.52 & 19.56 \\
\hline${ }^{* *}$ see explanatory notes in Table 3.
\end{tabular}

The calculated appearance energy is similar to the experimental one in case of production of two positively charged fragments; however, this process seems to be impossible in the near-threshold appearance energy area for the $m=28 \mathrm{Th}$ ion.

Our calculations of the appearance energy for the $\mathrm{CH}_{2} \mathrm{~N}^{+}$fragment according to the pathway (12) show that this process is not realized during the alanine molecule electron impact dissociation, i. e. the system does not reach its equilibrium state. Despite the minimal consumption of energy required to produce the final products according to the pathway (12), the experimental appearance energies for the $\mathrm{CH}_{2} \mathrm{~N}^{+}$fragment are most adequately described by pathways (9) and (10).

The structure of the $\mathrm{CH}_{2} \mathrm{~N}^{+}$ion depends on the parent or intermediate ion bonds being broken. Four possible relevant conformers were investigated in detail in our recent paper [35. It is important that in case when different bonds of the $\mathrm{CH}_{2} \mathrm{~N}^{+}$ cation are broken, the fragments become planar at their equilibrium point. Calculations [35] proved that the most stable structure of the $\mathrm{CH}_{2} \mathrm{~N}$ fragment is $\mathrm{H} 13-\mathrm{C} 1-\mathrm{N} 2-\mathrm{H} 6$. Note that $\mathrm{C}$ and $\mathrm{N}$ atoms in this case undergo the $s p$-hybridization.

For the ion with $m=18 \mathrm{Th}$ there are two possible compositions, i. e. $\mathrm{H}_{2} \mathrm{O}^{+}$and $\mathrm{NH}_{4}^{+}$. The yield curve for the $m / z=18$ ion measured in [9] has a threshold at $12.55 \pm 0.1 \mathrm{eV}$. Since this value is within the limits of an experimental error of the ionization energy determination for water $12.62 \pm 0.002 \mathrm{eV}$, the authors concluded that the fragment with $\mathrm{m} / z=18$ results from ionization of the water molecule, while formation of the $\mathrm{NH}_{4}^{+}$ion was not observed in [9], most probably, due to the fact that the cross section for this reaction is very low.

On the other hand, in [26] the $m / z=18$ ion was assigned to $\mathrm{NH}_{4}^{+}$with $\mathrm{HC}-\mathrm{CH}-\mathrm{COOH}$ as a neu- tral product. Referring to the analysis of the mass spectra for the $\alpha$-alanine- $\mathrm{d} 3$ molecule, the authors stated that the $\mathrm{NH}_{4}^{+}$ion contains two amino hydrogen atoms and two hydrogen atoms originally attached to the carbon skeleton. The formation of the $\mathrm{NH}_{4}^{+}$ion involves rearrangement processes, but the hydrogen atom attached to the carboxyl group is not favoured as a participating migrant one. According to the relative intensities of $\mathrm{m} / z=17$ and $\mathrm{m} / z=18$ peaks in the mass spectrum, the authors determined the maximum contribution of $\mathrm{H}_{2} \mathrm{O}^{+}$to the $m=18 \mathrm{Th}$ peak at the $20 \mathrm{eV}$ photon impact to be about $5 \%$ [26].

As seen from Fig. 2, the yield of the ion with the $m=18 \mathrm{Th}$ mass in our experiment is higher than that in other studies and is comparable to the $m=28 \mathrm{Th}$ ion yield. The semi-logarithmic presentation of our mass spectrum within the 15-20 Th mass range (see Fig. 6) allowed the splitting of the $m=18 \mathrm{Th}$ peak to be found which confirms experimentally the presence of the $\mathrm{H}_{2} \mathrm{O}^{+}$and $\mathrm{NH}_{4}^{+}$ions produced during alanine molecule dissociative ionization. The quantitative ratio of the $\mathrm{H}_{2} \mathrm{O}^{+}$to $\mathrm{NH}_{4}^{+}$peak intensities at the $60 \mathrm{eV}$ incident electron energy is 11.8:100, i. e. it almost twice exceeds the estimation made in [26] at the $20 \mathrm{eV}$ photon impact. It should be noted that our experiment was carried out within the molecular beam source temperature range that excluded thermal degradation of the initial alanine powder (i. e. within the $150-200{ }^{\circ} \mathrm{C}$ range). Thus, analysing fragmentation channels leading to the yield of the

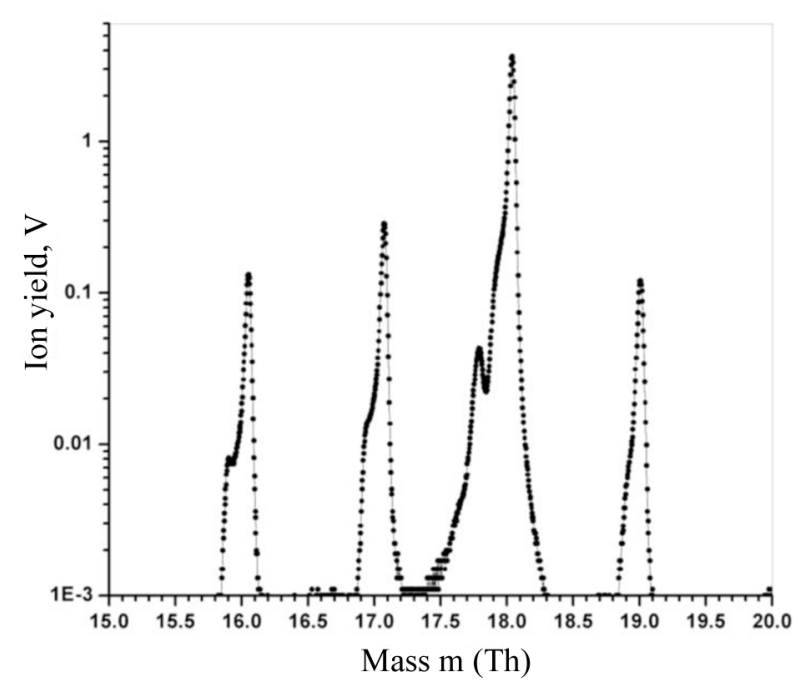

Fig. 6. Semi-logarithmic plot of the area of the alanine mass spectrum within the 15-20 mass range. 
ion with the $m / z=18$, ionization of water vapours released from the alanine sample at elevated temperatures may be excluded. The results calculated by us prove the fact that $\mathrm{H}_{2} \mathrm{O}^{+}$is formed by removing the $\mathrm{OH}$ and $\mathrm{H}$ fragments with subsequent formation of the $\mathrm{C}_{3} \mathrm{H}_{5} \mathrm{NO}$ neutral fragment. The possible pathways of the above positive ion formation could be as follows:

$$
\left\{\begin{array}{l}
(\mathrm{OH}+\mathrm{H})^{+}+\mathrm{C}_{3} \mathrm{H}_{5} \mathrm{NO}^{-}+\mathrm{e} \\
\mathrm{C}_{3} \mathrm{H}_{7} \mathrm{NO}_{2}+\mathrm{e} \rightarrow(\mathrm{OH}+\mathrm{H})^{+}+\mathrm{C}_{3} \mathrm{H}_{5} \mathrm{NO}^{0}+2 \mathrm{e},(15) \\
(\mathrm{OH}+\mathrm{H})^{+}+\mathrm{C}_{3} \mathrm{H}_{5} \mathrm{NO}^{+}+3 \mathrm{e} \\
\searrow_{\left(\mathrm{H}_{2} \mathrm{O}\right)^{+}}
\end{array}\right.
$$

It should be mentioned that we have checked several possibilities of formation of the water molecule. This means that we predicted that the $\mathrm{O} 4$, $\mathrm{O} 5$, or $\mathrm{OH}$ group and different $\mathrm{H}$ atoms could be detached under the low-energy impact. However, in all cases investigated the calculated appearance energy for the water molecule is higher than that measured by Ipolyi et al. [9] (see Tables 15, 16). Our theoretical analysis and experimental measurements performed at constant temperature prove

Table 15. Calculated appearance energies (in $\mathrm{eV}$ ) for the $\mathrm{C}_{3} \mathrm{H}_{5} \mathrm{NO}$ and $\mathrm{H}_{2} \mathrm{O}$ fragments produced from the ala-

\begin{tabular}{|c|c|c|c|}
\hline $\begin{array}{c}\mathrm{H}_{2} \mathrm{O} \\
(m=18 \mathrm{Th}) \\
\text { charge }\end{array}$ & $\begin{array}{c}\mathrm{C}_{3} \mathrm{H}_{5} \mathrm{NO} \\
(m=71) \\
\text { charge }\end{array}$ & $\begin{array}{c}\text { Alanine } \\
\text { molecule } \\
\text { geometry } \\
\text { not changed }\end{array}$ & $\begin{array}{l}\text { Alanine } \\
\text { molecule } \\
\text { geometry } \\
\text { changed }^{* *}\end{array}$ \\
\hline 1 & -1 & 19.39 & 14.32 \\
\hline 1 & 0 & 20.39 & 14.22 \\
\hline 1 & 1 & 28.68 & 21.52 \\
\hline
\end{tabular}
nine I molecule.

Table 16. Calculated appearance energies (in $\mathrm{eV}$ ) for the $\mathrm{C}_{3} \mathrm{H}_{5} \mathrm{NO}$ and $\mathrm{H}_{2} \mathrm{O}$ fragments produced from the alanine II molecule.

\begin{tabular}{c|c|c|c}
\hline $\begin{array}{c}(m=18 \mathrm{Th}) \\
\mathrm{H}_{2} \mathrm{O} \\
\text { charge }\end{array}$ & $\begin{array}{c}\mathrm{C}_{3} \mathrm{H}_{5} \mathrm{NO} \\
(m=71) \\
\text { charge }\end{array}$ & $\begin{array}{c}\text { Alanine } \\
\text { molecule } \\
\text { geometry } \\
\text { not changed }\end{array}$ & $\begin{array}{c}\text { Alanine } \\
\text { molecule } \\
\text { geometry } \\
\text { changed }\end{array}$ \\
\hline 1 & -1 & 23.79 & 15.43 \\
\hline 1 & 0 & 25.06 & 16.24 \\
\hline 1 & 1 & 24.35 \\
\hline \multicolumn{4}{c}{33.07} \\
\hline
\end{tabular}

that this ion could be formed due to joining one $\mathrm{H}$ atom and $\mathrm{OH}$ or two $\mathrm{H}$ atoms and the $\mathrm{O}$ atom. $\mathrm{On}$ the other hand, the above pathway of the appearance of the molecular water ion from the neutral water molecule could be possible in case of the alanine III molecule, because its stability is lower than that of the alanine I and alanine II molecules. This prediction is based on the analysis of alanine molecule isomerization. The results of our theoretical investigations indicate that the alanine I molecule may originate from the ground alanine III state due to the rotation of the $-\mathrm{COOH}$ group, and this post-translational reaction occurs via substance that modifies the transition state to lower the activation energy [35]. It implies that electron impact may cause isomerization of alanine when the water molecule is formed and ionized.

The ammonium ion $\mathrm{NH}_{4}^{+}$could be formed when the amino acid $\mathrm{NH}_{2}$ group joins two $\mathrm{H}$ atoms from different sides of the initial molecule. As for the hydrogen atom from the hydroxyl group, which is the nearest one to the nitrogen atom, it has been shown experimentally in [26] for the example of the deuterated alanine-d $3 \mathrm{~mol}-$ ecule that the $\mathrm{NH}_{4}$ fragment should be $\mathrm{ND}_{2} \mathrm{H}_{2}$, i. e. the hydrogen atom from the $\mathrm{OH}$ group does not take part in the $\mathrm{NH}_{4}$ fragment formation. On the other hand, attachment of the $\mathrm{H} 13$ atom is less probable for steric reasons. Thus, production of the ammonia ion at dissociative ionization of the alanine molecule seems to be possible in case of detachment of three hydrogen atoms from the methyl group via formation of relatively stable 4-term transient states. The results of calculation of the appearance energy of the $\mathrm{NH}_{4}^{+}$fragment for two alanine molecule conformers are presented in Tables 17 and 18. The ion-pair formation for the above two conformers is the most energetically beneficial process. In this case, the location of atoms of the alanine I and alanine II molecules has almost no influence on the appearance energy for the $\mathrm{NH}_{4}^{+}$ion. However, in case of the neutral complementary fragment formation, the alanine I molecule appears to be the most favourable to produce the ammonium ion.

As seen in the inset in Fig. 2, a weak peak related to the doubly charged $\mathrm{m} / \mathrm{z}=43.5$ ion is observed. Its atomic composition corresponds to the $\mathrm{C}_{3} \mathrm{H}_{5} \mathrm{NO}_{2}^{++}$ion, i. e. its production proceeds via detachment of two hydrogen atoms (most 
Table 17. Calculated appearance energies (in $\mathrm{eV}$ ) for $\left(\mathrm{NH}_{2}+2 \mathrm{H}\right)$ producing the $\mathrm{NH}_{4}$ and $\mathrm{C}_{3} \mathrm{H}_{3} \mathrm{O}_{2}$ fragments from the alanine I molecule.

\begin{tabular}{c|c|c|c}
\hline $\begin{array}{c}\mathrm{NH}_{4} \\
(\mathrm{~m}=18 \mathrm{Th}) \\
\text { charge }\end{array}$ & $\begin{array}{c}\mathrm{C}_{3} \mathrm{H}_{3} \mathrm{O}_{2} \\
(m=71 \mathrm{Th}) \\
\text { charge }\end{array}$ & $\begin{array}{c}\text { Alanine } \\
\text { molecule } \\
\text { geometry } \\
\text { not changed }\end{array}$ & $\begin{array}{c}\text { Alanine } \\
\text { molecule } \\
\text { geometry } \\
\text { changed }\end{array}$ \\
\hline 1 & -1 & 24.52 & 8.46 \\
\hline 1 & 0 & 24.70 & 9.69 \\
\hline 1 & 1 & 34.23 & 18.51 \\
\hline${ }^{*}{ }^{* *}$ see explanatory notes in Table 3.
\end{tabular}

Table 18. Calculated appearance energies (in $\mathrm{eV}$ ) for $\left(\mathrm{NH}_{2}+2 \mathrm{H}\right)$ producing the $\mathrm{NH}_{4}$ and $\mathrm{C}_{3} \mathrm{H}_{3} \mathrm{O}_{2}$ fragments from the alanine II molecule.

\begin{tabular}{c|c|c|c}
\hline $\begin{array}{c}\mathrm{NH}_{4} \\
\text { charge } \\
\text { ch }\end{array}$ & $\begin{array}{c}\mathrm{C}_{3} \mathrm{H}_{3} \mathrm{O}_{2} \\
(m=71 \mathrm{Th}) \\
\text { charge }\end{array}$ & $\begin{array}{c}\text { Alanine } \\
\text { molecule } \\
\text { geometry } \\
\text { not changed }\end{array}$ & $\begin{array}{c}\text { Alanine } \\
\text { molecule } \\
\text { geometry } \\
\text { changed }\end{array}$ \\
\hline 1 & -1 & 23.40 & 8.45 \\
\hline 1 & 0 & 25.03 & 12.94 \\
\hline 1 & 1 & 33.85 & 18.88 \\
\hline${ }^{*}{ }^{* *}$ see explanatory notes in Table 3.
\end{tabular}

probably, in the form of the $\mathrm{H}_{2}$ molecule) from the initial molecule. Such dissociation channel of the doubly charged alanine molecular ion with singly and multiply charged ion-induced ionization and fragmentation of alanine was not observed experimentally [32]. The authors found that as in the case of single ionization the main fragmentation process after double ionization is the scission of the $\mathrm{C} 1-\mathrm{C} 3$ bond. Upon the second ionization, the spatial distribution of the $\alpha$-alanine cation spin densities shows a substantial charge removed from the $\mathrm{COOH}$ group that corresponds to the HOMO-1 and/or HOMO-2 ionization. The $\mathrm{CH}_{3}$ group is only weakly affected by the removal of the second electron. Electron spin density distribution in the doubly charged molecular alanine ion allows one to suggest that elimination of hydrogen atoms from hydroxyl and amine groups is the most probable process.

Calculations of appearance energy for the $\mathrm{C}_{3} \mathrm{H}_{5} \mathrm{NO}_{2}^{++}$ion prove that the most energetically probable reaction in this case is

$$
\mathrm{C}_{3} \mathrm{H}_{7} \mathrm{NO}_{2}+\mathrm{e} \rightarrow \mathrm{C}_{3} \mathrm{H}_{5} \mathrm{NO}_{2}^{++}+(\mathrm{H}+\mathrm{H})^{-}+2 \mathrm{e} .
$$

Thus, the hydrogen molecular ion is not formed here.

\section{Conclusions}

The analysis of the alanine molecule mass spectrum accompanied by theoretical calculations allowed the main dissociation mechanisms of the above molecule under the low-energy electron impact to be determined. Most of the peaks in the experimental mass spectrum were identified. The appearance energies of the most pronounced ion peaks in the alanine molecule mass spectrum were measured experimentally and estimated theoretically. For the $\mathrm{C}_{2} \mathrm{H}_{4} \mathrm{~N}^{+}$ion $(m=42 \mathrm{Th})$, the optimization results indicate the changeability of the initial geometrical structure. The mechanism of the structural change $\mathrm{CH}_{3}-\mathrm{C}-\mathrm{NH}^{+} \rightarrow \mathrm{CH}_{3}-\mathrm{N}-\mathrm{CH}^{+}$ realized via intermediate cyclic structure is proposed.

It has been shown that three peaks with $m=27$, 28, 29 Th have a double-headed shape, thus, contribution of two ions to each peak was identified. As to the $m=28 \mathrm{Th}$ mass, we may conclude that two isobaric ions peaks in the experimental spectra belong to the $\mathrm{C}_{2} \mathrm{H}_{4}^{+}$and $\mathrm{CH}_{2} \mathrm{~N}^{+}$ions, while at the $70 \mathrm{eV}$ collision energy the channel of the $\mathrm{C}_{2} \mathrm{H}_{4}^{+}$ ion formation is more efficient than that for the $\mathrm{CH}_{2} \mathrm{~N}^{+}$ion. The experimentally observed stepwise structure in the ion yield curve for the alanine molecule fragment with the $m=28$ Th mass may be due not only to different pathways of the parent molecule dissociation, but also to the change of the charge of complementary particles produced and to the conformational isomerism as well.

We experimentally confirmed the production of the $\mathrm{H}_{2} \mathrm{O}^{+}$and $\mathrm{NH}_{4}^{+}$ions formed during alanine molecule dissociative ionization and established the quantitative ratio of the $\mathrm{H}_{2} \mathrm{O}^{+}$to the $\mathrm{NH}_{4}^{+}$ peak intensities at the $60 \mathrm{eV}$ incident electron energy.

Despite the fact that mass spectra show no unambiguous effect due to population of different conformers, the conformational isomerism may influence the near-threshold areas of ionization and dissociative ionization cross sections. Our calculations show that the presence of intramolecular hydrogen bonds and the differences in the locations of certain atoms in the conformational isomers may lead to the changes in the fragment appearance energies up to $2 \mathrm{eV}$. The conformational isomerism of the alanine molecule is revealed most distinctly during the formation of 
the ion with the $m=18$ Th mass in case of a zero charge of the complementary fragment.

Thus, variations of appearance energies for different conformers do exist and sometimes their values lie beyond the experimental error bars. Unfortunately, these peculiarities cannot be resolved in the present experiment.

\section{Acknowledgements}

The authors are grateful to prof. M. Cegla from Jagellonian University (Krakow, Poland) and our colleague V. Patašiene for their technical assistance. The InSpire, NGI.LT, and COST MP0802 projects are also acknowledged for the resources and technical support provided.

\section{References}

[1] R.F. Doolittle, Redundancies in protein sequences, in: Prediction of Protein Structures and the Principles of Protein Conformation, ed. G.D. Fasman (Plenum Press, New York, 1989) pp. 599-623, ISBN 0-30643131-9.

[2] G. Kreil, Ann. Rev. Biochem. 66, 337-345 (1997).

[3] D.F. Regulla and U. Deffner, Int. J. Appl. Radiat. Isot. 33, 1101-1114 (1982).

[4] M.Z. Heydari, E. Malinen, E.O. Hole, and E. Sagstuen, J. Phys. Chem. A 106, 8971-8977 (2002).

[5] V. Nagy, J.M. Puhl, and M.F. Desrosiers, Radiat. Phys. Chem. 57, 1-9 (2000).

[6] P. Schilke, C.M. Walmsley, T.J. Millar, and C. Henkel, Astron. Astrophys. 247, 487-496 (1991).

[7] Y. Hu and E.R. Bernstein, J. Chem. Phys. 128, 164311-164321 (2008).

[8] V. Feyer, O. Plekan, R. Richter, M. Coreno, K.C. Prince, and V. Carravetta, J. Phys. Chem. A 112, 78067815 (2008).

[9] I. Ipolyi, P. Cicman, S. Denifl, V. Matejcik, P. Mach, J. Urban, P. Scheier, T.D. Mark, and S. Matejcik, Int. J. Mass. Spectrom. 252, 228-233 (2006).

[10] V.S. Vukstich, A.I. Imre, and A.V. Snegursky, Tech. Phys. Lett. 35(12), 1071-1073 (2009).

[11] V.S. Vukstich, A.I. Imre, L.G. Romanova, and A.V. Snegursky, J. Phys. B 43, 185208 (2010).

[12] V.S. Vukstich, A.I. Imre, and A.V. Snegursky, Instr. Experim. Tech. 54(2), 207-213 (2011).

[13]Y. Zhao, J. Pu, B.J. Lynch, and D.G. Truhlar, Phys. Chem. Chem. Phys. 6, 673-676 (2004).

[14] R.A. Kendall, T.H. Dunning Jr., and R.J. Harrison, J. Chem. Phys. 96, 6796-6806 (1992).
[15] T.H. Dunning Jr., J. Chem. Phys. 90, 1007 (1989).

[16] R.C. Raffenetti, J. Chem. Phys. 58, 4452 (1973).

[17]J.T. Bursey, M.M. Bursey, and D.G.I. Kingston, Chem. Rev. 73, 231-233 (1973).

[18] M.W. Schmidt, K.K. Baldrige, J.A. Boatz, S.T. Elbert, M.S. Gordon, J.H. Jensen, S. Koseki, N. Matsunaga, K.A. Nguyen, S.J. Su, T.L. Windus, M. Dupuis, and J.A. Montgomery, J. Comput. Chem. 14, 1347-1363 (1993).

[19] Gaussian 03, Revision C.02, Gaussian Inc., Wallingford CT, 2004.

[20] H.M. Jaeger, H.F. Schaefer III, J. Demaison, A.G. Csaszár, and W.D. Allen, J. Chem. Theor. Comput. 6, 3066-3078 (2010).

[21] J.-H. Chen, L.-M. He, and R.L. Wang, J. Phys. Chem. A 117(24), 5132-5139 (2013).

[22] J. Luo, Z.Q. Xue, W.M. Liu, J.L. Wu, and Z.Q. Yang, J. Phys. Chem. A 110(43), 12005-12009 (2006).

[23] Ch.-G. Zhan, J.A. Nichols, and D.A. Dixon, J. Phys. Chem. A 107, 4184-4195 (2003).

[24] M. Schwell, H.-W. Jochims, H. Baumgartel, F. Dulieuc, and S. Leach, Planet. Space Sci. 54(11), 1073-1085 (2006).

[25] H.W. Jochims, M. Schwell, J.L. Chotin, M. Clemino, F. Dulieu, H. Baumgartel, and S. Leach, Chem. Phys. 298, 279-297 (2004).

[26] R. Stowasser and R. Hoffmann, J. Am. Chem. Soc. 121, 3414-3420 (1999).

[27] R.K. Singh, S.K. Verma, P.D. Sharma, Int. J. Chem Tech. Res. 3, 1571-1579 (2011).

[28]S. Bourcier and Y. Hoppilliard, Int. J. Mass Spectrom. 217(1-3), 231-244 (2002).

[29]NIST Chemistry WebBook, http://webbook.nist. gov/chemistry

[30] S. Simon, A. Gilb, M. Sodupeb, and J. Bertran, J. Mol. Struct. THEOCHEM 727(1-3), 191-197 (2005).

[31] S. Bari, P. Sobocinski, J. Postma, F. Alvarado, R. Hoekstra, V. Bernigaud, B. Manil, J. Rangama, B. Huber, and T. Schlathölter, J. Chem. Phys. 128, 074306-074311 (2008).

[32] A.F. Lago, L.H. Coutinho, R.R.T. Marinho, A. Naves de Brito, and G.G.B. de Souza, Chem. Phys. 307(1), 9-14 (2004).

[33]J. Tamuliene, L.G. Romanova, V.S. Vukstich, and A.V. Snegursky, Nucl. Instrum. Methods B 279, 128-134 (2012).

[34] J. Tamuliene, L.G. Romanova, V.S. Vukstich, and A.V. Snegursky, Chem. Phys. 404, 36-41 (2012).

[35] J. Tamuliene, L.G. Romanova, V.S. Vukstich, and A.V. Snegursky, Chem. Phys. 404, 74-81 (2012). 


\title{
ELEKTRONŲ SUKELTOS ALANINO MOLEKULĖS FRAGMENTACIJOS MECHANIZMAI
}

\author{
J. Tamulienè ${ }^{\text {a }}$, L.G. Romanova ${ }^{\text {b }}$, V. S. Vukstich ${ }^{\text {b }}$, A.V. Snegursky ${ }^{\text {b }}$ \\ ${ }^{a}$ Vilniaus universiteto Teorines fizikos ir astronomijos institutas, Vilnius, Lietuva \\ ${ }^{\mathrm{b}}$ Ukrainos mokslu akademijos Elektronu fizikos institutas, Užgorodas, Ukraina
}

\section{Santrauka}

Darbe pateikti alanino $\left(\mathrm{C}_{3} \mathrm{H}_{7} \mathrm{NO}_{2}\right)$ molekules fragmentacijos dèl žemos energijos elektronų poveikio eksperimentinių ir teorinių tyrimų rezultatai; neseniai išmatuotos ir apskaičiuotos fragmentų atsiradimo energijos ir identifikuoti smailių pikai, nustatyti tiriamos molekulès masès spektre, t. y. patikslinti ir papildyti kitų autoriu pateikti rezultatai. Nustatyta, kad $\mathrm{C}_{2} \mathrm{H}_{4} \mathrm{~N}^{+}$ $(m=42 \mathrm{Th})$ jono geometriné struktūra skiriasi nuo tos, kuri yra šio fragmento atskilimo nuo alanino molekulès momentu, t. y. $\mathrm{CH}_{3}-\mathrm{C}-\mathrm{NH}^{+} \rightarrow \mathrm{CH}_{3}-\mathrm{N}-\mathrm{CH}^{+}$geometrinès struktūros pakeitimai vyksta per tarpinę ciklinę struktūrą. Šis procesas nèra minimas kitų autorių darbuose.

Tik šio straipsnio autoriai pastebejjo, kad trijų smailių pikai, atitinkantys $m=27,28,29$ Th mases, turi dvigubas viršūnes. Tai rodo, kad alaniną paveikus lètaisiais elektronais susidaro keli vienodos masès, bet skirtingos cheminès sudèties fragmentai. Palyginus eksperimentiškai išmatuotą ir apskaičiuotą fragmentų susidarymo energijas, rasta, kad $m=28$ Th masès fragmentai yra $\mathrm{C}_{2} \mathrm{H}_{4}^{+}$ir $\mathrm{CH}_{2} \mathrm{~N}^{+}$jonai, nors $\mathrm{C}_{2} \mathrm{H}_{4}^{+}$jonu susidarymas yra labiau tikètinas. Kita vertus, autorių nustatyta laipsniška jonų išeigos kreivès struktūra parodo, kad alanino molekulès $m=28$ Th masès fragmentai, turintys teigiamą krūvị, galètų susidaryti ir dèl krūvio pasiskirstymo tarp komplementarių fragmentų ir alanino molekulès izomerizacijos.

Gauti rezultatai patvirtino, kad vykstant alanino molekulès disociatyviai fragmentacijai atsiranda $\mathrm{H}_{2} \mathrm{O}^{+}$ ir $\mathrm{NH}_{4}^{+}$jonai.

Nors remiantis išmatuotu alanino molekulès masès spektru negalima nustatyti, kurio alanino konformero fragmentacija yra stebima, autoriai pateikia išvadą, kad konformerų fragmentacija gali būti / yra skirtinga. Ši išvada grindžiama tuo, kad tokių pačių fragmentų, susidarančių iš skirtingų alanino konformerų, apskaičiuota atsiradimo energija skiriasi $2 \mathrm{eV}$. Šis skirtumas ypač ryškus $m=18$ Th masés jonų atveju. Tai rodo, kad nesutapimai tarp išmatuotos ir apskaičiuotos fragmentų atsiradimo energijos (dažnai pateikiama straipsniuose), viršijantys paklaidų ribas, gali atsirasti dèl skirtingų molekulių konformerų fragmentacijos. 